\title{
Nocardia asteroides ocular infection
}

\author{
Coimbatore Subramanian Shobana ${ }^{1 *}$, Haridas Sreekumar ${ }^{1}$, Prithiviraj Aiswariya ${ }^{1}$, Kanesan Panneer Selvam², \\ Yendrembam Randhir Babu Singh ${ }^{1}$, Perumal Gomathi ${ }^{3}$, Palanisamy Manikandan ${ }^{3}$
}

From 2nd International Science Symposium on HIV and Infectious Diseases (HIV SCIENCE 2014)

Chennai, India. 30 January - 1 February 2014

\section{Background}

Nocardia asteroides can cause ocular infection in immunocompetent and immunocompromised individuals following minor trauma. Hence present study was carried out to isolate $N$. asteroides from the patients attending a tertiary eye care hospital and to analyse the antibiotic susceptibility pattern of the Nocardia isolates.

\section{Methods}

The ocular samples viz., corneal swab, corneal scraping, aqueous tap and vitreous tap were processed for culture and the isolated Nocardia species were further confirmed for speciation by standard microbiological procedures. Antibiotic susceptibility analysis for the confirmed isolates of $N$. asteroides was performed by agar disk diffusion method following the guidelines of Clinical Laboratory Standard Institute (CLSI, 2000).

\section{Results}

Out of 280 ocular clinical specimens collected, 25 isolates of $N$. asteroides were obtained. The rest of the pathogens included bacteria, fungi and mixed culture. The age in most of the cases yielding Nocardia was below 5 years $(12 \%)$ and above 60 years $(52 \%)$ and men (76\%) were more infected than women (24\%). Precisely, 17 isolates of $N$. asteroides were isolated from corneal ulcer, 5 from corneal swab and 3 from endophthalmitis. Upon analysis of antibiotic susceptibility tests the nocardial isolates were found to be more susceptible to fourth generation fluoroquinolones antibiotic family (75\%), amikacin (66\%), ampicillin (80\%), vancomycin (50\%) and norfloxacin $(75 \%)$.

\section{Conclusion}

Ocular nocardiosis remains difficult to recognize, there by leading to misdiagnosis and underestimation of its incidence.

\section{Authors' details \\ ${ }^{1}$ Department of Microbiology, Dr. G.R. Damodaran College of Science, Coimbatore - 641 014, India. ²Department of Microbiology, M R Government Arts College, Mannargudi - 614 001, India. ${ }^{3}$ Department of Microbiology, Aravind Eye Hospital and Post Graduate Institute of Ophthalmology, Coimbatore - 641 014, India.}

Published: 27 May 2014

doi:10.1186/1471-2334-14-S3-P2

Cite this article as: Shobana et al:: Nocardia asteroides ocular infection. BMC Infectious Diseases 2014 14(Suppl 3):P2.

\footnotetext{
* Correspondence: shobana.cs@grd.edu.in

'Department of Microbiology, Dr. G.R. Damodaran College of Science,

Coimbatore - 641 014, India

Full list of author information is available at the end of the article
}

Submit your next manuscript to BioMed Central and take full advantage of:

- Convenient online submission

- Thorough peer review

- No space constraints or color figure charges

- Immediate publication on acceptance

- Inclusion in PubMed, CAS, Scopus and Google Scholar

- Research which is freely available for redistribution 